\title{
INTEGRÁCIÓS TÖREKVÉSEK A POSZTSZOVJET TÉRSÉGBEN - OROSZORSZÁG, KÍNA ÉS TÖRÖKORSZÁG JELENLÉTE
}

\author{
Integrational efforts in the post-Soviet region - Presence of \\ Russia, China and Turkey
}

\section{Ájben Katalin ${ }^{1}$ - Biró Dávid ${ }^{2}$}

\begin{abstract}
Absztrakt: A Szovjetunió felbomlásával létrejövő geopolitikai űr betöltésére számos jelentkező akadt az elmúlt évtizedekben. Egyes integrációs törekvések zászlóvivőjének szerepére olykor maga Oroszország vállalkozott. Az elmúlt évtizedekben tanúi lehettünk annak, miként értékelődött fel a posztszovjet térség, azon belül is Közép-Ázsia jelentősége. A térség gazdasági és politikai vezető szerepére Oroszország mellett idővel más nagyhatalmi vetélytárs is jelentkezett. Kína az elmúlt évtized talán legnagyobb nyertese lehet a térségért vívott „küzdelemben”. Ezen felül érdemes kiemelni Törökország szerepét is, amely a Türk Tanács létrehozását követően szintén meghatározó szereplője kíván lenni a térségnek. Jelen tanulmány célja, hogy bemutasson négy jellemző példát, szervezetet (Független Államok Közösség, Eurázsiai Gazdasági Unió, Sanghaji Együttmûködési szervezet, Türk Tanács) azon integrációs törekvésekre, amelyek valamely nagyhatalom égisze, iránymutatása alatt múködnek és e szervezetek jelentôs mértékben kapcsolódnak a posztszovjet közép-ázsiai régióhoz. Az elemzés során előtérbe kerül a szervezetek
\end{abstract}

1 Ájben Katalin, ELTE BTK Történelemtudományi Doktori Iskola Új- és Jelenkori Egyetemes Történelem Doktori Program, doktoranduszhallgató. Kutatási területe: Független Államok Közössége és Közép-Ázsia.

A szerző további munkásságát lásd a Magyar Tudományos Művek Tárában: https: $/ / \mathrm{m} 2 . \mathrm{mtmt}$. hu $/$ gui2 $/$ ?type $=$ authors\&mode=browse\&sel $=10073126$

2 Biró Dávid, ELTE BTK Történelemtudományi Doktori Iskola Új- és Jelenkori Egyetemes Történelem Doktori Program, doktoranduszhallgató. Kutatási területe: Törökország külpolitikája.

A szerző további munkásságát lásd a Magyar Tudományos Művek Tárában: https: $/ / \mathrm{m} 2 . \mathrm{mtmt}$. hu $/$ gui2 $/$ ?type $=$ authors\&mode=browse\&sel $=10073689$ 
felépítése, működése és legfontosabb tevékenységeik, eredményeik bemutatása.

Kulcsszavak: FÁK, Eurázsiai Gazdasági Unió, Sanghaji együttmúködési Szervezet, Türk Tanács

Abstract: There have been many applicants in recent decades to fill the geopolitical space created by the collapse of the Soviet Union. Russia itself has sometimes taken on the role of flag bearer in some integration efforts. In recent decades, we have witnessed an appreciation of the importance of the post-Soviet region, including Central Asia. In addition to Russia, other great power rivals have emerged as economic and political leaders in the region over time. China could be perhaps the biggest winner in the "fight" for the region, in addition, it is worth highlighting the role of Turkey, which, following the establishment of the Turkic Council, intends to be a key player in the region. The aim of this study is to present four typical examples, organizations (CIS, Eurasian Economic Union, Shanghai Cooperation Organization, Turkic Council) of integration efforts under the auspices of a great power and these organizations are significantly related to post-Soviet Central Asian region. During the analysis, the structure and operation of the organizations and the presentation of their most important activities and results come to the fore.

Keywords: CIS, Eurasian Economic Union, Shanghai Cooperation Organization, Turkic Council

\section{BEVEZETÉS}

Az integrációs folyamatok vizsgálatakor, egy adott szervezet létrejöttekor kulcskérdés lehet a politikai motiváció vizsgálata. Ezen túlmenően nem lehet kikerülni a gazdasági indíttatású integrációs kezdeményezéseket sem. A politikai és a gazdasági szempontok legtöbb esetben együttesen jelentkeznek a nemzetközi szervezetek létrehozásakor. Az általunk vizsgált együttműködések erősen kötődnek a posztszovjet közép-ázsiai térséghez és jellemzően valamely nagyhatalom vagy nagyhatalmak kezdeményezéseként jöttek létre, amelyek a tényleges vezető/iránymutató szerepet is betöltik a szervezeten belül. Oroszország történelmileg és kulturálisan is ezer szálon kötődik Közép-Ázsiához. 
Érezhető, hogy a Szovjetunió felbomlását követően is mind politikailag, mind gazdaságilag próbál kapcsolódni a régióhoz. Kína jelentôs gazdasági potenciállal rendelkező nagyhatalom a térségben, amelynek ugyan nincsenek olyan szoros történelmi, kulturális kapcsolatai a régióval, mint Oroszországnak, mégis világosan kirajzolódik az a gazdasági (és gyakran) kulturális térnyerés, amelyre Kína az elmúlt években törekszik. A legtöbb esetben Törökországot ki szokták felejteni abból a felsorolásból, amikor a vizsgált térség nagy és közepes hatalmait említik. A Türk Tanács 2009-es létrehozása óta Törökország évről-évre aktívabb szereplője kíván lenni a közép-ázsiai piacnak. Politikai, gazdasági és kulturális kapcsolatai egyre szerteágazóbbak a független türk országok körében, így fontosnak tartottuk, hogy foglalkozzunk Törökország szerepével.

A 2000-es évektől kezdve jelentősen megnőtt Eurázsia szerepe, egyértelműen egy új korszakról, Eurázsia időszakáról beszélhetünk. A gazdasági hatalom egyre inkább Kelet felé tolódik, így ennek kapcsán Közép-Ázsia országainak jelentősége is felértékelődik. Azonban továbbra is kérdéses, hogy miként képzelik el jövőjüket az érintett régió országai, mit várhatnak, és mit adhatnak azon integrációs szervezeteknek, amelyeknek maguk is a tagjai. Egyáltalán szükség van-e arra, hogy ennyi szervezetben képviseltessék magukat?

\section{OROSZORSZÁG INTEGRÁCIÓS TÖREKVÉSEI A POSZTSZOVJET TÉRSÉGBEN}

\subsection{Független Államok Közössége}

A Független Államok Közössége (a továbbiakban rövidítve: FÁK) a posztszovjet térség legnagyobb nemzetközi együttműködése, melyet Fehéroroszország, Oroszország és Ukrajna alapította, 1991. december 8-án Belozevszkaja Puscsában (Viszkulyban). ${ }^{3}$ A Közösség a Szovjetunió egykori tagországait tömöríti és bármely ország önkéntes alapon csatlakozhat hozzá, aki egyetért elveivel és céljaival. 1991. december 21-én Alma-Atában tizenegy államfő aláírta a megállapodási jegyzőkönyvét, amelynek értelmében Azerbajdzsán, Örményország, Fehéroroszország, Kazahsztán, Kirgizisztán, Moldova, Oroszország, Tádzsikisztán, Türkmenisztán, Üzbegisztán és Ukrajna tagjai lettek a FÁK-nak. 1993-ban egy újabb ország,

\footnotetext{
${ }^{3}$ ИНТЕРНЕТ-ПОРТАА СНГ.
} 
Grúzia csatlakozott a FÁK-hoz, amely 2009. augusztus 18-án kilépett a Közösségből, valamint Ukrajna 2014 óta nem vett részt a Közösség tevékenységében annak ellenére, hogy bármiféle hivatalos értesítést küldött volna a szervezetből való kilépéséről. ${ }^{4}$

Ahhoz, hogy valamelyik ország teljes jogú tagságot élvezzen, ratifikálnia kell az 1993. január 22-én elfogadott Minszki Chartát ${ }^{5}$, amely többek között tartalmazza a szervezet múködésének alappilléreit, illetve azokat a szabályokat, melyek előírják a tagság feltételeit, s a kooperálási területeket. Fellelhetőek benne a FÁK elvei és céljai. ${ }^{6}$

A FÁK céljai és elveit 1991. december 21 -én határozták meg AlmaAtában:

- együttmúködés politikai, gazdasági, környezetvédelmi, humanitárius, kulturális területen;

- tagállamok fejlesztése, közös gazdasági kereten belül, államközi együttmúködés és integráció;

- az emberi jogok és szabadságjogok biztosítása;

- a nemzetközi béke és biztonság biztosítása, az általános és teljes leszerelés érdekében

- kölcsönös jogsegély;

- a viták, konfliktusok békés megoldása. ${ }^{7}$

A közös tevékenységi területeknek:

- a tagállamok külpolitikájának az összehangolása;

- törekvés a közös gazdasági tér kialakítására; vámpolitika;

- egészség és környezetvédelem;

- társadalmi és migrációs politikai kérdések;

- közös küzdelem a szervezett bűnözés ellen. ${ }^{8}$

A szervezet keretein belül 84 testület jött létre, köztük 66 ágazati együttmúködés. Ezek közül a legfontosabbak: Államfők Tanácsa, Kormányfők Tanácsa, Külügyminiszterek Tanácsa, Határparancsnokság Parancsnokainak Tanácsa, Honvédelmi Miniszterek Tanácsa, Gazdasági Bizottság, Gazdasági Bíróság, Gazdasági Tanács, Végrehajtó Bizottság. ${ }^{9}$

\footnotetext{
${ }^{4}$ МИНИСТЕРСТВО ИНОСТРАННЫХ АЕА РОССИЙСКОЙ ФЕАЕРАЦИИ.

${ }^{5}$ МИНИСТЕРСТВО ИНОСТРАННЫХ АЕА РОССИЙСКОЙ ФЕАЕРАЦИИ.

${ }^{6}$ ИНТЕРНЕТ-ПОРТАА СНГ.

7 ААМА-АТИНСКАЯ АЕКААРАЦИЯ,1991.

8 ЕАИНЫЙ РЕЕСТР ПРАВОВЫХ АКТОВ И АРУГИХ АОКУМЕНТОВ СОАРУЖЕСТВА НЕЗАВИСИМЫХ ГОСУААРСТВ.

${ }^{9}$ ИНТЕРНЕТ-ПОРТАА СНГ.
} 
A FÁK létrejötte után az első néhány éveben tisztázásra kerültek A FÁK tagállamainak vezetői 1992. május 15-én aláírták a Kollektív Biztonsági Szerződést, létrehozták a Kollektív Biztonsági Tanácsot. ${ }^{10}$ Az 1994-es évtől kezdődően az integrációs folyamatok elmélyítésén dolgoztak. Az első évek során számos olyan szervezetet hoztak létre, amelynek célja, hogy növelje a szervezet hatékonyságát. 1998. április 29-én az államfők határozatot fogadtak el, amely a szervezeten belüli reformok és újítások miatt nagy jelentőséggel bírt. A FÁK Államfői Tanácsának 1999. április 2-i határozata nyomán született döntés a FÁK Végrehajtó Bizottságának létrehozásáról, mely a következő év során jött létre. 2002. május 15-én egyeztek meg a Kollektív Biztonsági Szerződés nemzetközi szervezetté való átalakításáról, melyre 2003-ban került sor, miután a tagállamok ratifikálták a megállapodást. A következő mérföldkőnek a 2004 szeptemberében megtartott csúcstalálkozó tekinthető, amelynek helyszíne Kazahsztán fővárosa, Asztana volt. A 2005. augusztus 26-án tartott kazanyi csúcstalálkozó különleges szerepet játszott a Nemzetközösség sorsában, ugyanis centrumában a FÁK jelentősége, megőrzése, illetve működési mechanizmusának javítása állt. Nem mellesleg a 2006-os évet a Független Államok Közösségének évévé nyilvánították. Dušanbében 2007. október 5én az államfők fontos döntést hoztak a Független Államok Közössége további fejlesztésének koncepciójáról és annak végrehajtásának fó intézkedési tervéről. A következô évben, 2008-ban Chișinăuban született döntés a 2020-ig tartó gazdasági fejlesztési stratégiáról. 2011. október 18-án Szentpéterváron jóváhagyták a Független Államok Közössége gazdaságfejlesztési stratégiájának második szakaszát (2012-2015), s annak a végrehajtására vonatkozó tervezetet, amely a 2020-ig tartó időszakot ölelte fel. A Szerződés aláírása új minőségi lépés a posztszovjet térség stratégiai kapcsolatainak fejlesztésében, gyakorlati megvalósítása javítja a FÁK tagállamaiban élők életszínvonalát. ${ }^{11}$

Az évek során aktívan fejlődött a FÁK országainak kapcsolata a kulturális és humanitárius szférában. 2000 óta hagyomány a tematikus évek szervezése. Ennek nyomán például 2009-et az Ifjúság évének, 2010-et a Tudomány és az Innováció évének, 2018-at a Kultúra évének nyilvánították. 2018. szeptember 28-án Dušanbében tartott ülésén a türkmén fél

10 Kollektív Biztonság Szerződés (oroszul: Организация Аоговора о колмективной безопасности.), létrejötte: 1992.05.12. Forrás: https://odkbcsto.org/documents/documents/dog ovorokollektivnoybezopasnosti/

11 СОАРУЖЕСТВО НЕЗАВИСИМЫХ ГОСУААРСТВ ЭКОНОМИЧЕСКИЙ СОВЕТ, 2014. 
kezdeményezésére a Nemzetközösség államfői aláírták a 2021-es építészet és városfejlesztés évének a FÁK-ban történő nyilvánításáról szóló határozatát. A Nemzetközösség szerveinek finanszírozása a szervezet egységes költségvetéséből történik, amelyet a tagállamok közös részvétele alapján alakítottak ki, és amelyet a FÁK kormányfőinek tanácsa hagyott jóvá. ${ }^{2}$

\begin{tabular}{|l|c|c|c|}
\hline \multicolumn{1}{|c|}{ Ország } & Lakosság (fö) & Terület $\mathbf{( k m}^{\mathbf{2}}$ & GDP (USD) \\
\hline Azerbajdzsán & 10023318 & 86600 & $48,0 \mathrm{mrd}$ \\
\hline Fehéroroszország & 9466856 & 207595 & $63,08 \mathrm{mrd}$ \\
\hline Kazahsztán & 18513930 & 2724900 & $181,7 \mathrm{mrd}$ \\
\hline Kirgizisztán & 6456900 & 199900 & $8,5 \mathrm{mrd}$ \\
\hline Moldova & 2657637 & 33846 & $11,9 \mathrm{mrd}$ \\
\hline Oroszország & 144373535 & 17098246 & $1,7 \mathrm{trd}$ \\
\hline Örményország & 2957731 & 29743 & $13,7 \mathrm{mrd}$ \\
\hline Tádzsikisztán & 9321018 & 141400 & $8,117 \mathrm{mrd}$ \\
\hline Üzbegisztán & 33580650 & 447400 & $57,9 \mathrm{mrd}$ \\
\hline
\end{tabular}

1. sz. táblázat. A FÁK tagországainak legfőbb mutatói (2019).

Forrás: data.worldbank.org

Fontos figyelembe venni, hogy a szervezet kulcsfontosságú szereplője Oroszország, mind geopolitika, mind pedig földrajzi és gazdasági helyzete miatt is. A kapacitások jelentős része az orosz technológiák alapján mûködik. Az orosz vállalatok meghatározó szereppel bírnak a FÁK gazdaságának fejlődésében. A Gazprom és Rosznyeft meghatározzák a FÁK gazdasági növekedésének dinamikáját. Mindezek mellett Oroszország társadalmi vonatkozása is fontos munkaerô szempontjából. Tulajdonképpen nehéz lenne elképzelni, hogy a FÁK megfelelően fejlődhetne Oroszország nélkül. Ugyanis az Orosz Föderáció felelősséget vállal a stabilitás fenntartásáért a FÁK régióban, valamint azokban az orosz katonai bázisokban, amelyek a Közösségen belül találhatók. ${ }^{13}$

Meg kell említeni, hogy a FÁK számos kihívással néz szembe, és ez érthető, mivel maga a posztszovjet térség a geopolitikai és gazdasági küzdelem színtere, ahol olyan globális szereplők vesznek részt a versengésben, mint Oroszország, az Amerikai Egyesült Államok, az Európai

\footnotetext{
12 ИНТЕРНЕТ-ПОРТАһ СНГ.

13 ИМЭМО РАН, 2019.
} 
Unió, és Kína, illetve az olyan regionális hatalmak sem maradnak távol, mint Törökország és Irán. Az utóbbi években a fö probléma az ukrajnai válság és a Krím annektálása volt. Ennek következtében a szervezet vezető országa ellen szankcióháború vette kezdetét, mely nemcsak az országot, de a Közösséget is negatívan érinti, kedvezőtlen hatással van a tagországok GDP-jének növekedésre, és az olajárakra. ${ }^{14} \mathrm{Ez}$ annak tudható be, hogy az EU megszakította a kapcsolatát Oroszországgal, a NATO pedig befagyasztotta Moszkvával az együttmúködést. ${ }^{15}$

\subsection{Eurázsiai Gazdasági Unió}

Az Eurázsiai Gazdasági Unió egy nemzetközi gazdasági szerveződés, egy szabadkereskedelmi övezet, amely a Közép- és Észak-Ázsiában, illetve a Kelet-Európában elhelyezkedő országokat is magában foglalja. Az Eurázsiai Gazdasági Unió (a továbbiakban rövidítve: EGU) lett a posztszovjet térségben az integráció legújabb víziója, amelyet 2014-ben Fehéroroszország, Kazahsztán és Oroszország alapított. A létrehozásáról szóló megállapodás 2015. január 1-jén lépett érvénybe ${ }^{16}$, amelynek mintájaként az Európai Unió szolgált. ${ }^{17} \mathrm{Az}$ Eurázsiai Gazdasági Uniót (továbbiakban: Unió) létrehozó szerződés azonban nem rögzítette az egységes valutaövezet létrehozását.

Az Unió fő céljai a következők:

- feltételek megteremtése a tagállamok gazdaságának stabil fejlődéséhez a lakosság életszínvonalának javítása érdekében;

- az áruk, szolgáltatások, tőke és munkaerőforrások egységes piacának kialakítása az Unión belül;

- átfogó modernizáció, együttmúködés és a nemzetgazdaságok versenyképességének növelése a globális gazdaságban. ${ }^{18}$

Az EGU működésének fő elvei:

- a nemzetközi jog általánosan elismert elveinek tiszteletben tartása, beleértve a tagállamok szuverén egyenlőségének és területi integritásának elveit;

- a tagállamok politikai struktúrája sajátosságainak tiszteletben tartása;

\footnotetext{
14 World ECONOMic Situation AND PRospects, 2015. 8.o.

15 Тренин, Амитрий, 2014.

16 ФЕАЕРААЬНАЯ НААОГОВАЯ САУЖБА.

${ }^{17}$ KISS - AIDA - SZABÓ, 2021.

18 МИНИСТЕРСТВО ИНОСТРАННЫХ АЕА РОССИЙСКОЙ ФЕАЕРАЦИИ.
} 
- a kölcsönösen elônyös együttmúködés, az egyenlőség és a Felek nemzeti érdekeinek figyelembevétele;

- a piacgazdaság és a tisztességes verseny elveinek betartása;

- vámunió kivételek és korlátozások nélküli múködése az átmeneti idôszakok lejárta után. ${ }^{19}$

Az EGU szervei: a Legfelsőbb Eurázsiai Gazdasági Tanács, az Eurázsiai Kormányközi Tanács az Eurázsiai Gazdasági Bizottság és Bíróság. ${ }^{20}$ A tervek szerint 2025-ig egy nemzetek feletti testületet hoznak létre, amely a pénzügyi piac szabályozására fog törekedni és a tervek szerint az Unió alapvető részévé fog válni.

Az együttműködés előzményei, alapjai az 1990-es évekre nyúlnak vissza. Az Eurázsiai Gazdasági Uniót fokozatosan hozták létre. A rendszerváltás után a posztszovjet térség országai gazdaságilag elmaradottak voltak, legtöbbjük esetében begyűrűzött a gazdasági válság, infláció sújtotta őket, emiatt az Eurázsiai integráció folyamata nem volt zökkenőmentes, lassan haladt. A megalapítás első lépései az 1990-es évekre tehetőek. 1994ben Nurszultan Nazarbajev a Moszkvai Állami Egyetemen tartott beszédében felvetette az „Eurázsiai Unió” létrehozásának gondolatát, amely egy regionális kereskedelmi blokként funkcionálna, s egy valóban múködő államunió képét festette le. Megalapítását azzal indokolta, hogy ez elősegítené az áruk szabad áramlását Eurázsia szerte, FÁK-tól eltérően egyértelmúbb és részletesebb intézményi struktúrával, hatáskörrel kellene rendelkeznie a gazdaság kulcsfontosságú ágazataiban. A posztszovjet tér országainak vezetői azonban ebben az időben nem voltak felkészülve egy „új unió” létrehozására, ebből adódóan egy idő után ezt az elképzelést csak Fehéroroszország és az Orosz Föderáció támogatta. ${ }^{21}$

Mindazonáltal 1995-ben Fehéroroszország, Kazahsztán és Oroszország aláírta a vámunió megalapítására irányuló szerződést, azonban ez soha nem lépett életbe, az 1990-es évek centrifugális erői túl erősek voltak. $^{22}$ 1996-ban Fehéroroszország, Kazahsztán, Oroszország és Kirgizisztán aláírta a fokozottabb gazdasági és humanitárius integrációról szóló szerződést. 1999-ben Fehéroroszország, Kazahsztán, Oroszország, Kirgizisztán és Tádzsikisztán is ellátta kézjegyével a vámunióról és az

\footnotetext{
${ }^{19}$ ИНТЕРНЕТ-ПОРТАА СНГ.

${ }^{20}$ ИНТЕРНЕТ-ПОРТАА СНГ.

21 ЗИНОВЬЕВ ВАСИАИЙ ПАВАОВИЧ - ТРОИЦКИЙ ЕВГЕНИЙ ФАОРЕНТЬЕВИЧ, 2016. 241.o.

22 VINOKUROV, 2018. 3.o.
} 
egységes gazdasági térségről szóló szerződést, az egységes gazdasági térség megalapítása végett. ${ }^{23}$

Az integráció következő lépcsőfoka a 2000-es évekre tehető. 2000ben Fehéroroszország, Kazahsztán, Oroszország, Kirgizisztán és Tádzsikisztán létrehozta az Eurázsiai Gazdasági Közösséget, amelyhez 2006-ben Üzbegisztán is csatlakozott. A szerződés értelmében egy közös piac jött létre a tagállamok részére, alapjául az Európai Gazdasági Közösség szolgált.

A 2003-as év során Fehéroroszország, Kazahsztán, Oroszország és Ukrajna aláirta, majd 2004-ben ratifikálta az Egységes Gazdasági Térség létrehozásáról szóló szerződést. ${ }^{24}$ Ellenben ezen folyamat a 2004-es narancsos forradalom miatt elakadt. Szocsiban 2006-ban ismét terítékre került a vámunió és a közös gazdasági térség kialakításának gondolata. A „trojka” (Fehéroroszország, Kazahsztán és az Orosz Föderáció) tagjai újfent aktívan részt vettek a szerveződés kialakítására irányuló munkálatokban, döntésekben. Megállapodás született arról, hogy a Kirgizisztán és Tádzsikisztán csatlakozhat az elfogadott határozathoz, amint gazdaságilag elég fejlettek lesznek. Egy évvel később, 2007 októberében egyezmény született a közös vámterület létrehozásáról és a vámunió kialakításáról. ${ }^{25}$

A kooperáció létrehozásának utolsó ciklusa a 2010-es évekre tehető. 2010. január 1-jén életbe lépett Fehéroroszország, Kazahsztán és Oroszország vámuniója, amely a blokkon belüli vámok megszüntetését és a közös vámpolitika kialakítását célozta meg. 2011. november 18-án Kazahsztán, Oroszország és Fehéroroszország elnöke elfogadta az eurázsiai gazdasági integrációról szóló nyilatkozatot, amely bejelentette az áttérést az integráció építésének következő szakaszára - a közös gazdasági térre. 2012. január 1-jén 17 államközi megállapodás lépett hatályba, melyek megalapozták megalakulásának jogi feltételét. A megszűnt Vámuniós Bizottság helyébe az Eurázsiai Gazdasági Bizottság került. Ugyanezen év március 19-én a Legfelsőbb Eurázsiai Gazdasági Tanács ülésén úgy határoztak, hogy 2015. január 1-ig átfogó megállapodást írnak alá az Eurázsiai Gazdasági Unió megalakításáról. 2014. május 29-én Asztanában a Fehéroroszország, a Kazahsztán és Oroszország elnöke aláírta az Eurázsiai Gazdasági Unióról szóló szerződést, amely 2015. január 1-jén lépett

${ }^{23}$ САРКИСЯН, 2017.

24 Egységes Gazdasági Térség (oroszul: ЕАиное экономическое пространство) megalapítása: 2003.09.19. Forrás: http://www.kremlin.ru/supplement/1715.

25 IFCG ЭНЦИКАОПЕАИЯ. 
hatályba. ${ }^{26}$ Az aláírási ünnepségen jelen voltak Kirgizisztán és Örményország elnökei is. Vlagyimir Putyin kijelentette: „Ma létrehoztunk egy eröteljes, vonzó és fejlödó gazdasági kö̈pontot, egy nagy regionális piacot, amely több mint 170 millió embert egyesit.

2014. október 10-én Minszkben a felek megállapodtak Örményország EGU-hoz történő csatlakozásáról. ${ }^{28}$ A dokumentumot az Eurázsiai Legfelsőbb Gazdasági Tanács ülésén fogadták el, amelyen a tagállamok vezetői vettek részt. Ugyanezen a napon Alekszandr Lukasenko, Nurszultan Nazarbajev és Vlagyimir Putyin elnök „ütemtervet” hagyott jóvá a Kirgizisztán Közös Gazdasági Térségéhez való csatlakozásáról. A ratifikációs eljárások befejezése után, 2015. augusztus 12-én Kirgizisztán az Unió teljes jogú tagjává vált. ${ }^{29}$

\begin{tabular}{|l|c|c|c|}
\hline \multicolumn{1}{|c|}{ Ország } & Lakosság (fö) & Terület $\mathbf{( k m}^{\mathbf{2})}$ & GDP (USD) \\
\hline Fehéroroszország & 9466856 & 207595 & $63,08 \mathrm{mrd}$ \\
\hline Kazahsztán & 18513930 & 2724900 & $181,7 \mathrm{mrd}$ \\
\hline Kirgizisztán & 6456900 & 199900 & $8,5 \mathrm{mrd}$ \\
\hline Oroszország & 144373535 & 17098246 & $1,7 \mathrm{trd}$ \\
\hline Örményország & 2957731 & 29743 & $13,7 \mathrm{md}$ \\
\hline
\end{tabular}

2. sz. táblázat. Az EGU tagországainak legfőbb mutatói (2019). Forrás: data.worldbank.org

Az EGU létrejötte után számos szerződés született annak érdekében, hogy az együttmúködés hatékonyan funkcionáljon. 2015. július 21 -én Szíria bejelentette csatlakozási szándékát az Unióhoz. 2015. május 29-én Burubajban, az EGU és Vietnám megállapodást írtak alá a szabadkereskedelmi zóna létrehozásáról ${ }^{30}$, melyet egy évvel később május 2án ratifikáltak. 2017. január 17-én Igor Dodon Moldova elnöke bejelentette, hogy országa az EGU-ban megfigyelőként kíván részt venni, ezt 2018. május 14-én el is fogadták. 2018. január 1-jén hatályba lépett az Unió új vámkódexe, amely a vámtechnológia digitalizálásával jelentős könnyítést jelentett az áruszállításban. ${ }^{31}$ Május 17 -én ideiglenes megállapodást írtak alá a

\footnotetext{
26 ВИНОКУРОв, 2017. 26.о.

27 ГA3ETA.RU, 2014.

28 ЭАЕКТРОННЫЙ ФОНА.

29 ЭАЕКТРОННЫЙ ФОНА.

30 КАПИТАА, 2015.

31 ЕВРАЗИЙСКОГО ЭКОНОМИЧЕСКАЯ КОМИССИЯ, 2017.
} 
szabadkereskedelmi övezetről Iránnal, a kereskedelmi kapcsolatok megkönnyitése és megerősítése végett. ${ }^{32} \mathrm{Az}$ adott év októberében lépett hatályba a Kínával kötött kereskedelmi és gazdasági együttmúködésről szóló megállapodás. ${ }^{33} \mathrm{Ez}$ azonban „mindössze” keretet jelent, platformot hozott létre, ahol az EGU tagállamai és Kína képviselői megvitathatják a bilaterális kereskedelmi megállapodásokat. A következő lépés egy szabadkereskedelmi zóna létrehozása lehet az EGU és Kína között.

Mivel a szerveződés orosz vezetéssel jött létre, így Oroszország geopolitikai helyzete és stabilitása is hatással van rá. A 2014-es ukrán válság és az, hogy Ukrajna társulási szerződést írt alá az EU-val, számos integrációs és strukturális nehézséget okozott az együttmúködésen belül. Az EU tartózkodott a hivatalos kapcsolat kialakításától az EGU-val. A szervezetet főleg egy oroszok által uralt geopolitikai eszköznek tekintették, amelyet abból a célból hoztak létre, hogy az orosz hegemóniáját helyreállítsa a posztszovjet térben. Ebben a kontextusban nem meglepő, hogy az EU korlátozta Oroszországgal fenntartott kapcsolatait. A 2014-2019 közötti időszakban csökkent az áruk szállítása a szervezet tagországai között. Az olaj, a gáz és a villamos energia egységes piacainak a létrehozását 2025-re tervezik, de még nem hoztak döntést arról, hogy ezek a piacok hogyan múködhetnek. Továbbá megjegyzendő, hogy az Unión belül integrációs problémát okoz, hogy a tagállamok véleménye eltérő az Oroszországgal való mélyebb együttmúködés kérdésében. Kazahsztán, Kirgizisztán, Tádzsikisztán, Türkmenisztán és Üzbegisztán is érdekelt ez EU-ban a kereskedelem és az ásványkincsek révén. Például Kazahsztán az olaj import miatt, Türkmenisztán pedig a földgáz miatt tekinthető az EU számára vonzó partnernek. Az EU segítséget nyújt a közép-ázsiai partnereknek a határbiztonság kezelésében és a kábítószer-kereskedelem elleni küzdelemben. Illetve a 2007-2013 közötti időszakban az országok támogatásban részesültek, amely az oktatásra, a regionális biztonságra, a természeti erőforrások fenntartható kezelésére és a társadalmi-gazdasági fejlődésre összpontosított. 2013 óta rendszeresen zajlik az EU és KözépÁzsia közötti magas szintű politikai és biztonsági párbeszéd. Jelenleg Közép-Ázsia minden országában vannak EU-küldöttségek. ${ }^{34}$ Közép-Ázsia országai sokvektoros külpolitikát alkalmaznak, legtöbb tagállam (Kazahsztán, Kirgizisztán, Fehéroroszország) nem marad kizárólag azon

\footnotetext{
32 ААЬТА СОФТ, 2018.

${ }^{33}$ EURASIA DAILY, 2019.

${ }^{34}$ EUROPEAN PARLIAMENT
} 
vonalak mentén melyeket Oroszország irányoz elő törekednek a külső partnerekkel való kooperációra. Mivel, úgy tartják, hogy Oroszország a szervezetet felhasználva igyekszik saját gazdasági és geopolitikai helyzetét megerősíteni. ${ }^{35}$

\section{KÍNA ÉS OROSZORSZÁG NAGYHATALMI KÜZDŐTERE: A SANGHAJI EGYÜTTMÜKÖDÉSI SZERVEZET}

A Sanghaji Együttműködési Szervezet (a továbbiakban rövidítve: SCO) elődjét az ún. „Sanghaji ötöket” 1996-ban hozták létre, amikor Kína, Oroszország, Kazahsztán, Kirgizisztán és Tádzsikisztán aláírta a Sanghaji Megállapodást a közös határ menti területek biztonságának kiépítéséről, majd 1997. április 24-én ugyanazok az országok Moszkvában aláírták a határrégiók katonai erőinek visszaszorításáról szóló szerződést. ${ }^{36}$ Ennek a kezdeti formációnak az volt a célja, hogy ellensúlyozza az érintett országok közötti feszültséget és határvitákat, amelyek a Szovjetunió 1991-es összeomlása következtében felszínre kerültek. Üzbegisztán 2001-es csatlakozásával a „Sanghaji ötök” „Sanghaji Együttműködési Szervezetté” alakult át. Pakisztán és Indiai 2017-es csatlakozásával 8 tagállam rendelkezik teljes jogú tagsággal. Fehéroroszország, Afganisztán, Irán, Mongólia megfigyelői státusszal, még Örményország, Azerbajdzsán, Törökország, Kambodzsa, Nepál és Srí Lanka tárgyalópartnerei a szervezetnek. Türkmenisztán, a Délkelet-ázsiai Nemzetek Szövetsége (ASEAN) és a Független Államok Közössége (FÁK) szintén gyakran vesz részt megfigyelőként az egyeztetéseken. ${ }^{37} \mathrm{Az}$ SCO hivatalos nyelve az orosz és a kínai. A szervezet alapokmányát az SCO államfők találkozóján, 2002. júniusában írták alá Szentpéterváron, és 2003. szeptember 19-én lépett hatályba. Ez a dokumentum felvázolja a szervezet céljait és alapelveit, valamint szerkezetét és alaptevékenységét. Az SCO központi ideológiájában fontos szerepet kapott a vallási szélsőségességek, az etnikai szeparatizmus és a nemzetközi terrorizmus felszámolása. ${ }^{38}$

Az SCO fő célkitűzései a következőek:

- a tagállamok közötti kölcsönös bizalom erősítése;

35 Clingendael Spectator, 2020.

36 AL-QAHTANI, 2006. 129.o.

37 FIDH - SHANGHAi COOPERATION ORGANISATION: A VEHICLE FOR HUMAN RIGHTS VIOLATIONS, 2012. 9.o.

38 GRAINGER, 2012. 28.o. 
- hatékony együttműködésük elősegítése a politikai téren, a kereskedelemben, a gazdaságban, a kutatásban, a technológiában és a kultúrában, valamint az oktatás, az energiaügy, a közlekedés, az idegenforgalom, a környezetvédelem és más területeken;

- közös erőfeszítések a béke, biztonság és stabilitás fenntartása és biztosítása érdekében a régióban;

- a demokratikus keretek elősegítése, fenntartása;

- tisztességes és ésszerú új nemzetközi politikai és gazdasági rend kialakítása. ${ }^{39}$

\begin{tabular}{|l|c|c|c|}
\hline \multicolumn{1}{|c|}{ Ország } & Lakosság (fö) & Terület $\mathbf{( k m}^{\mathbf{2}}$ & GDP (USD) \\
\hline India & 1366417754 & 3287259 & $2,869 \mathrm{trd}$ \\
\hline Kazahsztán & 18513930 & 2724900 & $181,7 \mathrm{mrd}$ \\
\hline Kína & 1398000000 & 9596961 & $14,28 \mathrm{trd}$ \\
\hline Kirgizisztán & 6456900 & 199900 & $8,5 \mathrm{mrd}$ \\
\hline Oroszország & 144373535 & 17098246 & $1,7 \mathrm{trd}$ \\
\hline Pakisztán & 216565318 & 796000 & $278,222 \mathrm{mrd}$ \\
\hline Tádzsikisztán & 9321018 & 141400 & $8,117 \mathrm{mrd}$ \\
\hline Üzbegisztán & 33580650 & 447400 & $57,9 \mathrm{mrd}$ \\
\hline
\end{tabular}

3. sz. táblázat. A SCO tagországainak legfőbb mutatói (2019). Forrás: data.worldbank.org

Az SCO tagjai és megfigyelői státusszal rendelkező országai együttesen a világ területének és erőforrásainak jelentős részét, valamint a világ népességének több mint felét magukban foglalják, továbbá jelentős katonai potenciállal is rendelkeznek. Az SCO célja a tagországok közötti béke és stabilitás megteremtése a biztonság és politikai kapcsolatok, a kereskedelem és a kulturális együttmúködések segítségével. A szervezet mára az oktatás, az idegenforgalom, a környezetvédelem, a kultúra, a tudomány és a technológiai fejlesztések területén is előremutató programokat, együttműködéseket tesz lehetővé. ${ }^{40}$ Annak ellenére, hogy a tagországok földrajzilag szoros kapcsolatban állnak, történelmük, gazdasági hátterük, nyelvük, nemzeti érdekeik, kormányzati struktúrájuk jelentősen eltér egymástól, amely nagymértékben befolyásolta és olykor hátráltatta az SCO fejlődését, előrehaladását. Ennek kapcsán élesedtek a kritikai hangok

\footnotetext{
39 The SHANGHAi COOPERATION ORgANiSATION

${ }^{40}$ Grainger, 2012. 1.o.
} 
az SCO jövőbeni szerepét illetően. ${ }^{41}$ Kérdéses, hogy elsősorban politikaikatonai szervezetként kell-e definiálnia magát, vagy intenzív üzleti együttmúködésként kell működnie a jövőben, hasonlóan az ASEAN-hoz és más szervezetekhez.

A biztonsági-stratégiai szövetségről a gazdasági együttműködésre való áttéréshez nagyobb szintû bizalomra, elkötelezettségre és jogi keretekre van szükség. Oroszország és Kína kapcsolatának erősítése, a bizalom iránti fokozott igény, a kábítószer-kereskedelem és az illegális bevándorlás azok a súlyos belső tényezők, amelyekkel a szervezetnek egyre inkább szembesülnie kellett. Noha a bővítések, a növekvő közvetlen külföldi befektetések kezelése és a nem tagokkal való jobb kapcsolattartás is egyértelmű kihívást jelentett a tagországok számára. Szervezeti szempontból az SCO-t alapvetően kormányközi hálózatként hozták létre, amelyek éves csúcstalálkozók és a tagállamok kormányfőinek, külügyminisztereinek és más magas rangú tisztviselőinek rendszeres találkozóit jelentette. A biztonság szempontjából fontos kérdéseket, témákat a megbeszéléseken az információbiztonsági szakértők, nemzetbiztonsági tanács titkárai és a legfelsőbb bíróságok vezetői vitatják meg. A gazdasági és egyéb funkcionális együttmúködések is egyre növekvő hangsúllyal jelennek meg ezen találkozók alkalmával, ideértve az SCO potenciális energetikai szerepét is. Már 2005 októberében létrehozták az SCO Bankközi Szövetséget és az SCO Üzleti Tanácsot, amelynek 2006. júniusi alakuló ülésén 500 üzletember vett részt. ${ }^{42}$

Az Államfői Tanács (HSC) az SCO legfőbb döntéshozó testülete. Évente egyszer ülésezik, döntéseket és iránymutatásokat fogad el a szervezetet érintő minden fontos kérdésében. Az SCO Kormányzói Tanácsa (HGC) évente egyszer ülésezik, hogy megvitassák a szervezet multilaterális együttmúködési stratégiáját és kiemelt területeit, megoldják az aktuális fontos gazdasági és egyéb együttmúködési kérdéseket, valamint jóváhagyják a szervezet éves költségvetését. Ezeken felül a Biztonsági Tanács titkárai; külügyi, védelmi, gazdasági, közlekedési, kulturális, oktatási és egészségügyi miniszterek; a bűnüldöző szervek, és a legfőbb ügyészek szintjén is rendszeresen üléseznek a szervezet képviselői, delegáltjai. Az SCO tagállamok Nemzeti Koordinátorainak Tanácsa (CNC) az SCO koordinációs mechanizmusaként múködik. A szervezetnek két állandó szerve van - a pekingi székhelyú SCO titkárság és a Taskentben található

\footnotetext{
41 AKINER, 2010. 25.o.

42 BAILES ET AL., 2007. 5.o.
} 
Regionális Terrorizmusellenes Hálózat (RATS) Végrehajtó Bizottsága. Az SCO főtitkárát és az SCO RATS Végrehajtó Bizottságának igazgatóját az államfők tanácsa nevezi ki hároméves időtartamra. Vlagyimir Norov (Üzbegisztán) és Jumakhon Giyosov (Tádzsikisztán) 2019. január 1-je óta tölti be ezeket a tisztségeket. ${ }^{43}$

Az SCO titkárságának állandó létszáma 30 fó, és a titkárság éves költségvetése mintegy 3 millió USD, amelynek nagy részét Kína és Oroszország finanszírozza, hozzájárulásuk egyenként $24 \% .{ }^{44} \mathrm{Ez}$ az összeg a múködési költségeken kívül alig fedez többet, így a titkárság munkáját nagymértékben az alapigazgatásra korlátozza. Minden olyan ügyben, amely sérti a nemzeti érdekeket vagy joghatóságot, konzultációt kell folytatni a nemzeti koordinátorokkal. Kezdeményezések történtek a titkárság szerepének, befolyásának növelésére, nagyobb finanszírozására, de eddig kevés eredménnyel. ${ }^{45}$

A RATS 30 munkatársa közül hetet Kína és Oroszország, hatot Kazahsztán, ötöt Üzbegisztán, hármat Kirgizisztán és kettőt Tádzsikisztán delegál. ${ }^{46}$ Oroszország lényegében kifogásolja, míg a közép-ázsiai államok létfontosságúnak tartják az SCO struktúrájának jelenlegi, meglehetősen decentralizált jellegét, hogy megvédjék szuverenitásukat a kínai - orosz dominanciától.

2005. április 12-én aláírták az SCO titkársága és a FÁK Végrehajtó Bizottsága közötti egyetértési megállapodást. A dokumentum meghatározza az együttmúködés kiemelt területeit, például a regionális és nemzetközi biztonság szavatolását, így a terrorizmus, a szélsőségek, a szeparatizmus, a kábítószer- és fegyverkereskedelem, a szervezett és a transznacionális bűnözés elleni küzdelmet. ${ }^{47}$ Ezen felül a kereskedelem, az áruk, a szolgáltatások és a finanszírozás, a beruházások, a közlekedés és a kommunikáció, a környezetvédelem, az informatika és az idegenforgalom és a humanitárius szféra (kultúra, oktatás, tudomány és egészségügy) támogatását és védelmét.

2009. június 16-án, a jekatyerinburgi csúcstalálkozón Kína bejelentette, hogy 10 milliárd dolláros hitelt kíván nyújtani más SCOtagországoknak, hogy a globális pénzügyi válság közepette fellendítse tagjai

\footnotetext{
43 The SHANGHAi COOPERATION ORgANISATION

44 AKINER, 2010. 13.o.

45 BAILES ET AL., 2007. 13.o.

46 BAILES ET AL., 2007. 5.o.

47 The Shanghai CoOperation Organisation
} 
gazdaságát. ${ }^{48}$ A csúcstalálkozót az első BRICS csúcstalálkozóval együtt tartották, és a Kína - Oroszország közös nyilatkozatában kiemelte, hogy nagyobb kvótát akarnak a Nemzetközi Valutaalapban. ${ }^{49}$

Az SCO-t gyakran kritizálták az eredmények csekély látszata miatt, és a „sokkal több retorika, mint cselekvés” elve miatt. ${ }^{50}$ A kritika föként a politikai akarat és a belső kohézió hiányára utaltak, azon intézményi és strukturális gyengeségekre, amelyek a bejelentett kezdeményezések és azok tényleges végrehajtása közötti szakadékot eredményezik. A végrehajtás hiányosságai a pénzügyi források hiányához, valamint a tagok bel- és külpolitikájának sokféleségéhez kapcsolódnak. Az együttműködés, az „egységes energiapiac” vagy az Energiaklub létrehozására irányuló 2006-os orosz kezdeményezés példaként szolgál. ${ }^{51}$ A hagyományos biztonsági és gazdasági együttmúködés területén Oroszország és Kína közötti rivalizálás és eltérő nézeteik komolyan akadályozták a további előrelépést az SCO integrációjában. ${ }^{52}$

Kínával ellentétben Oroszország jelentős kezdeményezésnek tartotta, hogy megerősítsék az SCO - CSTO katonai együttmúködést, míg Kína egy SCO szabadkereskedelmi övezet létrehozását szorgalmazta a gazdasági integráció fellendítése érdekében. Ezt nemcsak Oroszország, hanem a közép-ázsiai államok is elfogadhatatlan versenynek tekintették. Nagy hiányosság mutatkozik az SCO biztonsági testületében is, amit az is bizonyít, hogy nem tudott konstruktív elkötelezettséggel reagálni az olyan helyzetekre, mint a 2010-es zűrzavarra a kirgizisztáni Oszban. Figyelembe véve a be nem avatkozás elvét és a kollektív reakciómechanizmus hiányát, az SCO passzív álláspontot foglalt el. ${ }^{53} \mathrm{Ez}$ megkérdőjelezi biztonsági szervezetként fennálló létjogosultságát. Míg az SCO tagjai elítélték a 2008-as orosz inváziót Grúzia ellen, hallgattak Oroszország Krím-félsziget általi 2014-es annektálásáról. Az ENSZ Közgyúlésének krími határozatáról szóló szavazáson az SCO minden tagja tartózkodott, annak ellenére, hogy azok egyértelmúen ellentétesek voltak az SCO alapelveivel és nyilatkozataival. Egyre inkább kirajzolódnak azok a tényezők, amelyek hátráltatják az SCO

\footnotetext{
48 ChINA DAILY, 2009.

${ }^{49} \mathrm{IMF}, 2009$.

50 Plater-ZybeK - Monaghan, 2014. 18.

51 Shavialiova, 2013.

${ }^{52}$ Hussain, 2011. 243-272.o.

53 INTERNATIONAL CRISIS GROUP, ASIA REPORT NO. 244. 2013. 23.o.
} 
működését, fejlődését, így kérdéses, hogy egy ilyen szervezetnek milyen jövője van az egyre inkább felértékelődő közép-ázsiai régióban. ${ }^{54}$

\section{TÖRÖKORSZÁG VEZETŐ SZEREPE A POSZTSZOVJET TÉRSÉGBEN - A TÜRK TANÁCS}

A török nyelvű államok együttmúködését biztosító szervezetet, azaz a Türk Tanácsot (Türk Keneşi) 2009-ben hozták létre. A török nyelvü államok csúcstalálkozóinak folyamata a Szovjetunió 1991-es felbomlása után fórumként jött létre, a Törökországgal nyelvi kapcsolatban álló országok, nevezetesen a Dél-Kaukázusban található Azerbajdzsán és Kazahsztán, Üzbegisztán, Türkmenisztán és Kirgizisztán részvételével. Az 1992-ben Törökország kezdeményezéseként elindított folyamat keretében tíz „török nyelvű ország államfői csúcstalálkozót" tartottak. A Nakhichevanban tartott 9. csúcstalálkozón Törökország, Azerbajdzsán, Kazahsztán és Kirgizisztán a jelenlegi folyamat intézményesítése céljából aláírta a Nakhchivani megállapodást ${ }^{55}$ a Türk Nyelvú Államok Együttmúködési Tanácsa létrehozásáról, így ismertebb nevén létrejött a „Türk Tanács” szervezete. ${ }^{56}$

A Tanács céljai között szerepelt, hogy segítse a török nyelvú államok közötti együttmúködést, legyen szó akár politikai, gazdasági vagy éppen kulturális kapcsolatokról. A tanács négy alapító országot tudhat a sorai között: Törökországot, Azerbajdzsánt, Kazahsztánt és Kirgizisztánt. Az évek során további tagokkal bővült a Türk tanács. A korábban megfigyelői státuszú Üzbegisztán 2018-ben teljes jogú tagja lett a tanácsnak, valamint Magyarország ${ }^{57}$ megfigyelői státuszt kapott.

A Türk Tanács elsődleges célkitűzései:

- kölcsönös bizalom és a politikai szolidaritás megerősítése a türk világban;

- a béke és stabilitás megerősítése;

- széleskörű együttműködések létrehozása a tagországok között;

- gazdasági és technikai együttmúködési lehetőségek felgyorsítása;

- a türk világ történelmi és kulturális értékeinek széles körű bemutatása;

\footnotetext{
${ }^{54}$ LANTEIGNE, 2017. 131.o.

55 NAKHCHIVAN AgREEMENT, 2009.

56 SCHNITZER- SKJOSBERG, 2017. 11-12.o.

57 VASA, 2021. 3-16.o.
} 
- a török nyelvű országok közötti mélyebb kapcsolatok kiépítésével új regionális együttmúködések létrehozása. ${ }^{58}$

A tagállamok földrajzi és geopolitikai fekvése okán a szervezet elsősorban Eurázsiában, de inkább Közép-Ázsiában és a Kaukázusban tudja érdekeit határozottabban képviselni. A török tanács a közös történelem, a közös nyelv, a közös identitás és a közös kultúra négy fő oszlopára épül, de egyértelműen látszik, hogy kizárólagosan nem korlátozódik ezen elvekre. A gazdaság, a tudomány, az oktatás, a közlekedés, a vámügyek, az idegenforgalom fejlesztését egyaránt meghatározó a tagállamok körében. A multilaterális együttműködések elsősorban a régió fejlesztését szolgálják, ám azon túlmutatóan a globális térben is kamatoztatni tudják ezen hasznokat. Továbbá a Türk Tanács nem korlátozódik a tagok közötti együttmüködésre. A Tanács elvei kiterjednek a regionális szomszédságpolitika gyümölcsöző együttmúködésére annak érdekében, hogy biztosítsák a békét és a stabilitást a régióban. ${ }^{59}$

\begin{tabular}{|l|c|c|c|}
\hline \multicolumn{1}{|c|}{ Ország } & Lakosság (fö) & Terület (km²) & $\begin{array}{c}\text { GDP (milliárd } \\
\text { USD) }\end{array}$ \\
\hline Azerbajdzsán & 10023318 & 86600 & 48,0 \\
\hline Kazahsztán & 18513930 & 2724900 & 181,7 \\
\hline Kirgizisztán & 6456900 & 199900 & 8,5 \\
\hline Törökország & 83429615 & 783356 & 761,4 \\
\hline Üzbegisztán & 33580650 & 447400 & 57,9 \\
\hline
\end{tabular}

4. számú táblázat. A Türk Tanács tagállamainak főbb mutatói (2019).

Forrás: data.worldbank.org

A törökül beszélő államok 2010. szeptember 15-16-án, Isztambulban tartott 10. csúcstalálkozóján létrehozták a török nyelvű államok együttmúködési tanácsát. Az isztambuli csúcstalálkozón a török származású Halil Akıncit (2010-2014) nevezték ki a Tanács fötitkárává. Őt követte az azeri Ramil Hasanov (2014-2018), majd a kazah Bagdad Amreyev (2018-). A szervezet megalakulása óta hét csúcstalálkozót tartottak Almatiban, Biskekben, Gabalában, Bodrumban, Asztanában, Cholpon-Atában és Bakuban. Ezt az éves nagy eseményt a tagállamok elnökeinek,

\footnotetext{
58 TURKIC COUNCIL

${ }^{59}$ SCHNITZER- SKJOSBERG, 2017. 12.o.
} 
külügyminisztereinek és adott esetben más miniszterek részvételével hívják össze. ${ }^{60}$

A Türk Tanács legfőbb szervei az Államfők Tanácsa, a Külügyminiszterek Tanácsa, a Bölcsek/Vének Tanácsa, a Vezető Tisztségviselők Tanácsa és a Titkárság. A Türk Tanács legfőbb döntő testülete az Államfők Tanácsa, amelynek elnöke a hivatalban lévő elnöki tisztet betöltő ország (betűrend szerinti rotáció), a jelenlegi elnök Azerbajdzsán. A Türk Tanács tevékenységét az Isztambulban található titkárság koordinálja és támogatja. ${ }^{61}$

A török nyelvű országok együttműködési tanácsa, a török nyelvű országok között számos együttműködési mechanizmus, ernyőszervezet is múködik. A Türksoy-t, a Török Kultúra Nemzetközi Szervezetét 1993-ban hozták létre. Központja Ankarában található. A Türksoy támogatja a tagok közötti együttmúködést a tudomány, az oktatás, a kultúra és a múvészet területén, nemzetközi szinten népszerüsítve terjeszti a török világ közös értékeit, és erősíti a kulturális kapcsolatokat a török nyelvű államok között. ${ }^{62}$ A Türkpa-t, a Türk-nyelvű Országok Parlamenti Közgyúlését, a 2008-ban aláirt isztambuli megállapodással hoztak létre. Központja Bakuban található. A Közgyúlés célja az együttműködések erősítése a török nyelvű országok parlamentjei között. ${ }^{63}$

Török Üzleti Világtanács alapító okiratát 2011-ben írták alá. A Török Üzleti Világtanács fontos szerepet játszik a Türk Tanács erőfeszítéseiben a gazdasági együttműködés fokozása érdekében négy ország magánszektorbeli intézményeinek összefogásával. A Kereskedelmi Kamarák elnökei évente egyszer üléseznek a Török Üzleti Tanács szervezésében. A Tanács 5. ülését 2017. április 3-án Asztanában tartották, és határozatot hoztak a Török Üzleti Világanács alá tartozó titkárság létrehozásáról, isztambuli székhellyel. ${ }^{64}$

A tudományos és kulturális kapcsolatok kutatását, valamint együttműködést segítő Nemzetközi Türk Akadémiát 2012-ben hozta létre Kazahsztán, Törökország, Azerbajdzsán és Kirgizisztán. Az Asztanában található Nemzetközi Türk Akadémia célja a török nyelv, irodalom, kultúra, történelem és néprajz területén végzett tudományos kutatások koordinálása

\footnotetext{
60 TURKIC COUNCIL

${ }^{61}$ IDRISSOV, 2015. 11.o.

${ }^{62}$ Kaseinov, 2015. 19-23.o.

63 Asanov, 2015. 25-28.o.

64 Turkic COUNCIL
} 
és támogatása. Az Akadémia további célja, hogy láthatóvá tegye a törökség hozzájárulását a világ civilizációihoz azáltal, hogy kutatásokat végez és publikál a türk nemzetek kulturális és szellemi örökségéről. A Török Kulturális Örökség Alap alapító okiratát 2012-es biskeki csúcstalálkozón írták alá. Az Alapítvány célja a török kulturális örökség védelme A Türk Kulturális Örökség Alap a Türksoy-al és a Nemzetközi Türk Akadémiával együttmúködve végzi feladatait. ${ }^{65}$

A Török Kereskedelmi és Iparkamara (a továbbiakban rövidítve: TCCI) alapító okiratát 2019. május 17-én, az Astana Economic Forum keretein belül, a török üzleti tanács tagintézményeinek részvételével írták alá. A TCCI titkárságának szolgáltatásait a Törökországi Kamarák és Árutőzsdék Szakszervezete (rövidítve: TOBB) látja el. A török jogszabályokkal összhangban a TCCI napirendjén szerepelnek a jogi személyek és a nemzetközi státusz megszerzésére irányuló tevékenységek. A 2019. október 5-én Taskentben és október 14-én Bakuban tartott üzleti fórumok kiváló példaként szolgáltak a török világban folytatott kereskedelmi kapcsolatok fokozására. Magyarország és Üzbegisztán a bakui Üzleti Fórum során lett a TCCI tagja. ${ }^{66}$

Az 1990-es évekhez képest Törökország gazdasági és politikai lehetőségei, valamint mozgásterei jelentős mértékben megváltoztak. Az új geopolitikai környezet lehetôvé tette Ankara számára, hogy egyre aktívabb politikát folytasson keleten. Azonban Törökországnak egyszerre kell megküzdenie a régióban Oroszország és Kína nagyhatalmi törekvéseivel. Egy saját „össztörök” szervezet, mint a Türk Tanács, Törökország politikai, gazdasági és stratégiai pozícióit tudják erősíteni a régióban. Ám arról sem szabad megfeledkezni, hogy a Türk Tanács legtöbb tagjának különböző érdekeltségei vannak más orosz és kínai szervezetekben is. A Tanács szerepe a közeljövőben várhatóan meg fog nőni, köszönhetően a gazdasági lehetőségeiknek, hiszen a tagországok jelentős földgáz és kőolajkészletekkel rendelkeznek. Továbbá a szervezet aktív szereplője kíván lenni a Kína által életre hívott „Egy Övezet Egy Út” (rövidítve: OBOR) kezdeményezésnek is. ${ }^{67}$

\footnotetext{
65 Turkic COUNCIL

${ }^{66}$ Turkic COUNCIL

${ }^{67}$ EGERESI, 2021.
} 


\section{KONKLÚZIÓ}

Összefoglalásként elmondható, hogy a Független Államok Közösségének nem sikerült regionális szervezetté alakulnia, múltja és kapcsolatrendszere ellenére sem. Ez azért tekinthető jelentős problémának, mert emiatt gazdaságilag sem tud kellőképpen fejlődni. Azonban meg kell állapítanunk, hogy a FÁK 30 éves története során a negatív előrejelzések ellenére, képes volt fennmaradni, megvédeni létjogosultságát és több szempontból lehetőséget biztosított a tagországok számára a gazdasági fejlődésre, valamint politikai, társadalmi, katonai, kulturális és más programok területén is aktívnak bizonyult. A számos belső ellentmondás és külső nyomás ellenére is fenntartotta egységét és olyan programokat irányzott elő, melyek a fejlődését segítették.

Az EGU kézzelfogható előnyökkel jár a tagállamoknak, s azok állampolgárainak. Azonban az évek előrehaladtával egyre közelebb kerülhet ahhoz, hogy megvalósíthatatlan elképzeléssé váljon, mivel a tagállamok és az Unió szervezetei rendkívüli módon bürokratikusak és a tagországok heterogén jellege is hátráltatja a folyamatok eredményességét. Tekintettel arra, hogy az EGU orosz vezetéssel múködik, így integrációjában hatalmas előrelépést eredményezne, ha rendeződne Oroszország külkapcsolata az EU-val és az USA-val.

A sanghaji együttmúködési szervezet a tagállamok területéből és bruttó hazai terméküket figyelembe véve jelentős előnnyel bírnak a hasonló célokkal rendelkező más szervezetekkel szemben. Mégis azt látjuk, hogy a SCO mintha egyhelyben toporogna, és nem kerülnek/kerültek felszínre azok az eredmények, amelyeket a szervezet megpróbál hangoztatni. Sokkal inkább azt látjuk, hogy e szervezet inkább Kína és Oroszország nagyhatalmi és nemzetközi küzdőtere. Úgy tűnik, hogy ez a két óriás nem férne meg egymás mellett és más elképzelések mentén haladnának tovább. A két ország küzdelme nagyban befolyásolja a szervezet sikerességét, fejlődését. Ezen felül a tagországok sokszínúsége sem feltétlenül jelent garanciát a jövőbeni célok elérésére.

Törökország viszonylag új hatalomként van jelen a közép-ázsiai régióban. Történelmi és kulturális gyökerei jó alapot biztosíthatnak a gyümölcsöző együttmúködéseknek. Politikai, gazdasági, etnikai, kulturális téren is több bilaterális és multilaterális projekt megvalósításán dolgoznak, amelyek jelentős része megpróbál illeszkedni Kína új(abb) kezdeményezéséhez is az „Egy övezet, egy út” projekt vonatkozó részeihez. 
Továbbra is nagy kérdés, hogy Törökország mennyiben tud érvényesülni a régióban olyan nagyhatalmak mellett, mint Kína vagy Oroszország. Ezen szervezetek akkor tudnák elérni célkitűzéseiket, ha befektetések szempontjából csábítóak lennének akár az EU vagy USA számára is. Kiemelendő, hogy ezen kapcsolatok szélesítésére az utóbbi időben több példát is tudunk említeni. Ide sorolhatjuk Magyarország megfigyelői státuszát a Türk Tanácsban, amely számos gazdasági előnnyel járhat KözépEurópa és Magyarország számára is ${ }^{68}$ A legnagyobb kérdés talán mégis az, hogy melyik nagyhatalom kerül ki győztesen az eurázsiai piacokért folytatott küzdelemből, megfér-e egymás mellett több sikeres szervezet, vagy folytonos ellenségeskedéssel kell számolnunk.

\section{FELHASZNÁLT IRODALOM}

AkINER, SHIRIN (2010): The Shanghai Cooperation Organization: A Networking Organization for a Networking World, London Global Strategic Forum, June. Elérhető: $\quad$ https://www.globalstrategyforum.org/wpcontent/uploads/The-Shanghai-Cooperation-Organisation.pdf (Letöltve: 2021.03.20.)

Al-QAhTANi, MutLaq (2006): The Shanghai Cooperation Organization and the Law of International Organizations, Chinese Journal of International Law, Vol. 5, Issue 1. (Letöltve: 2021.03.20.)

ААМА-АТИНСКАЯ АЕКААРАЦИЯ [Alma-Atyinszakaja Deklaracija.]

Elérhető:

http://cis.minsk.by/reestr/ru/index.html\#reestr/view/text?doc $=4$ (Letöltve: 2021.04.30.)

Asanov, Jandas (2015): TurkPa: The Parliamentary Dimension of Cooperation Among Turkic Countries. In Fifth Summit of the Turkic Council entitled Fifth Summit of the Turkic Council: A Raising Actor in Regional Cooperation in Eurasia. Elérhetô: https://www.turkkon.org/en/yayinlar/5th-summit-of-the-turkiccouncil-special-publication 3 (Letöltve: 2021.03.25.)

A $\Lambda$ bTA СОФт [Alta szoft] (2018): Elérhető:

https://www.alta.ru/tamdoc/18bn0101/ (Letöltve: 2021.02.04.)

Bailes K. J. A. - Dunay P. - Guang P. - Troitskiy M. (2007): The Shanghai Cooperation Organization, SIPRI Policy Paper No. 17. Elérhető:

${ }^{68}$ VASA, 2021. 3-16.o. 
https://www.sipri.org/sites/default/files/files/PP/SIPRIPP17.pdf (Letöltve: 2021.03.22.)

CHINA DAILY (2009): Elérhető:

https://www.chinadaily.com.cn/china/2009sco/200906/16/content 8289602.htm (Letöltve: 2021.03.22.)

CLINGENDAEL SPECTATOR

(2020):

Elérhetô:https://www.clingendael.org/publication/eu-eurasianeconomic-union-common-chinese-challenge (Letöltve:2021.03.04.)

ВИНОКУРОВ, ЕВГЕНИЙ ЮРЬЕВИЧ (2017): Евразийский Экономический Союз. [Vinokurov, Jevgenyij Jurijevics: Jevrazijszkij Ekonomicseszkij Szojuz.] Центр интеграционных исследований Санкт-Петербург 26.

ГA3ETA.RU [Gazeta.ru] (2014). Elérhető: https://www.gazeta.ru/business/news/2014/05/2 9/n 6191161.shtml(Letöltve: 2021.03.03.)

EGERESI ZOLTÁN (2021): Intézményesedő türk együttműködés: a Türk Tanács.

Eléretô:

https://www.ludovika.hu/magazin/aula/2021/04/08/intezmenyesedoturk-egyuttmukodes-a-turk-tanacs/ (Letöltve(2021.05.05.)

EgYSÉGES GAZDASÁGI TÉRSÉG (ЕАиное экономическое пространство). Elérhető: http://www.kremlin.ru/supplement/1715.

EURASIA DAILY (2019): Elérhető:

https://eadaily.com/ru/news/2019/11/12/soglashenie-eaes-s-kitaemsozdaet-platformu-dlya-ustraneniya-torgovyh-barerov

(Letöltve:2021.03.04.)

EUROPEAN

PARLIAMENT.

Elérhető:

https://www.europarl.europa.eu/factsheets/en/sheet /178/central-asia (Letöltve:2021.05.01.)

ЕВРАЗИЙСКИЙ ЭКОНОМИЧЕСКИЙ СОЮ3. [Jevrazijszkij Ekonomicseszkij Szojuz.] Elérhető: http://www.eaeunion.org/\#about (Letöltve: 2021.03.02.)

ЕВРАЗИЙСКОГО ЭКОНОМИЧЕСКАЯ КОМИССИЯ. एеvrazijszkovo Ekonomicseszkaja Komisszija.] (2017): Elérhető: http://www.eurasiancommission.org/ru/nae/news/Pages/14 11 17.as px (Letöltve: 2021.02.04.)

ЕАИНЫЙ РЕЕСТР ПРАВОВЫХ АКТОВ И АРУГИХ АОКУМЕНТОВ СОАРУЖЕСтвА НЕЗАВИСимых ГОсуаАсттв. [Jedinij Reesztr Pravovih Aktov i Drugih Dokumentov Szodruzsesztva Nezaviszmih Goszudarsztv.]

Elérhető: 
Integrációs törekvések a posztszovjet térségben - Oroszország, Kína és Törökország jelenléte

http://cis.minsk.by/reestr/ru/index.html\#reestr/view/text?doc $=4$ (Letöltve: 2021.03.09.)

FIDH (2012): Shanghai Cooperation Organisation: a vebicle for buman rights violations. Elérhető: https://www.fidh.org/IMG/pdf/sco report.pdf (Letöltve: 2021.03.18.)

GRAINGER, STEPHEN (2012): The Shanghai Cooperation Organization (SCO): Challenges Ahead and Potential Solutions, ECU Publication. Elérhető: https: $/ /$ ro.ecu.edu.au/cgi/viewcontent.cgi?article $=1159 \&$ context $=$ ecuw orks2012 (Letöltve: 2021.03.21.)

Hussain, ImTiaz (2011): The Shanghai framework and Central Asia: Chop-suey governance? In Kirchner, Emil J. - Dominguez, Roberto szerk.: The Security Governance of Regional Organizations, Routledge.

ЗИНОВЬЕВ ВАСИАИЙ ПАВАОВИЧ - ТРОИЦКИЙ ЕВГЕНИЙ ФАОРЕНТЬЕВИЧ (2016): Евразийская экономическая интеграчия: эволючия, проблемь и иерспективы. [Zinovjev Vaszilij Pavlovics - Troickij Jevgenyij Florentyevics: Jevrazijszkaja ekonomicseszkaja integracija: evolucija, problemi, i perszpektivi.] Русин № 4. Elérhető: https://core.ac.uk/download/pdf /287417571.pdf (Letöltve: 2021.05.02.)

IDRISSOV, ERDAN (2015): The Turkic Council: Engine of Turkic Integration. In Fifth Summit of the Turkic Council entitled Fifth Summit of the Turkic Council: A Raising Actor in Regional Cooperation in Eurasia. Elérhető: https://www.turkkon.org/en/yayinlar/5th-summit-of-the-turkiccouncil-special-publication 3 (Letöltve: 2021.03.25.)

IFCG ЭНЦиклОПЕАИЯ. [IFCG Enciklopedija] Elérhető: https://bit.ly/3unzbso (Letöltve: 2021.05.01.)

IMF (2009):

Elérhető:

https://www.imf.org/en/News/Articles/2015/09/28/04/53/sorea072 209a (Letöltve: 2021.03.22.)

INTERNATIONAL CRISIS GROUP, ASIA REPORT No. 244. (2013): Elérhető: https://d2071 andvip0wj.cloudfront.net/chinas-central-asia-problem.pdf (Letöltve: 2021.03.22.)

ИмЭмо РАН [Imejmo Ran.] (2019): Elérhető:

https:// www.afjournal.ru/index.php?page id=132(Letöltve: 2021.03 .11$.

ИнтерНеТ-ПортА^ СНГ. [Internet Portal SzNG.] Elérhető: https://ecis.info/page/3509/80702/ (Letöltve 2021.03.11.)

ИнтерНЕТ-ПортАл СНГ. [Internet Portal SzNG.] Elérhető: https://ecis.info/page/3367/79789/ (Letöltve 2021.03.11.) 
ИнтерНеТ-ПортАл СНГ. [Internet Portal SzNG.] Elérhető: http://www.e-cis.info/page.php?id=19397 (Letöltve: 2021.03.09.)

ИнтерНеТ-ПортА^ СНГ. [Internet Portal SzNG.] Elérhető: https://ecis.info/news/566/55743/ (Letöltve: 2021.03.03.)

ИНТЕРНЕТ-ПОРТАА СНГ. [Internet Portal SzNG.] Elérhetô: https://web.archive.org/web/20110704204817/http://cis. minsk.by/reestr/ru/index.html\#reestr/view/text?doc $=187 \#$ reestr $/$ view $\angle$ text?doc $=187$ (Letöltve: 2021.03.09.)

ИнтерНеТ-ПортАл СНГ. [Internet Portal SzNG.] Elérhető: https://ecis.info/news/566/557 43/ (Letöltve:2021.05.01.)

KASEINOV, DUSEN (2015): TURKSOY: The Global Actor of Cultural Cooperation in the Turkic World. In Fifth Summit of the Turkic Council entitled Fifth Summit of the Turkic Council: A Raising Actor in Regional Cooperation in Eurasia. Elérhetô:

https://www.turkkon.org/en/yayinlar/5th-summit-of-the-turkiccouncil-special-publication 3 (Letöltve: 2021.03.25.)

КАПИТАА

[Kapital]

(2015):

Elérhetô:

https://kapital.kz/economic/40223/yeaes-i-v-yetnam-zaklyuchatsoglasheniye-29-maya.html (Letöltve:2021.03.04.)

KOLLEKTíV BIZTONSÁg SZERZŐDÉS ( Организация Аоговора о колмективной безопасности.) Elérhető: https://odkbcsto.org/documents/documents/dog ovorokollektivnoybezopasnosti/ (Letöltve:2021.05.01.)

KISS LILLA NÓRA - AIDA, BEKTASHEVA - SZABÓ BALÁZS (2021): Eurasian Economic Union: in the EU's footsteps or on new paths. In: Przegląd Europejski. 24.

Lanteigne, Marc (2017): Russia, China and the Shanghai Cooperation Organization: Diverging Security Interests and the 'Crimea Effect'. In Blakkisrud, Helge -Rowe, Elana Wilson szerk.: Russia's Turn to the East, Domestic Policymaking and Regional Cooperation. Global Reordering. Elérhető: https://link.springer.com/content/pdf/10.1007\%2F978-3-319-697901.pdf (Letöltve: 2021.03.22.)

МИНИСТЕРСТВО ИНОСТРАННЫХ АЕА РОССИЙСКОЙ ФЕАЕРАЦИИ. [Minyisztersztvo Inosztrannikh Gyel Rosszijszkoj Federaciji.] Elérhető: https://www.mid.ru/o-razvitii-sotrudnicestva-v-ramkah-sodruzestvanezavisimyh-gosudarstv.(Letöltve: 2021.03.09.)

МИНИСТЕРСТВО ИНОСТРАННЫХ АЕА РОССИЙСКОЙ ФЕАЕРАЦИИ. . [Minyisztersztvo Inosztrannikh Gyel Rosszijszkoj Federaciji.] Elérhető: 
Integrációs törekvések a posztszovjet térségben - Oroszország, Kína és Törökország jelenléte

https://www.mid.ru/integracionnye-struktury-prostranstvasng//assetpublisher/rl7Fzr0mbE6x / content/id/145436. (Letöltve: 2021.03.09.)

МИНИСТЕРСТВО ИНОСТРАННЫХ АЕА РОССИЙСКОЙ ФЕАЕРАЦИИ. [Minyisztersztvo Inosztrannikh Gyel Rosszijszkoj Federaciji.]Elérhető: https://www.mid.ru/razvitie-evrazijskogo-ekonomiceskogo-souza/Lasset publisher/uFvfW VmCb4Rl/content/id/934661 (Letöltve: 2021.03.03.)

NAKHCHIVAN AGREEMENT (2009): Elérhető:

https://www.turkkon.org/assets/pdf/temel belgeler/nakhchivanagreement-on-the-establishm ent-of-the-copperation-council-of-turkicspeaking-states-1-en.pdf (Letöltve: 2021.03.23.)

РАМБ $\Lambda$ ЕР [Rambler] (2018): Elérhető:

https://finance.rambler.ru/economics/39839215-evraziyskiyekonomicheskiy-soyuz-dose/(Letöltve:2021.03.04.)

САРКИСяН, ТИГРАН (2017): Евразийская экономическая интеграчия: чифры и факты. Библиотека Евразийской интеграчии. [Szarkiszjan, Tigran: Jevrazijszakaja ekonomicseszkaja inetgracija:cifri i fakti. Bibliotyeka jevrazijszkoj integraciji.]

СОАРУЖЕСТВО НЕЗАВИСИМЫХ ГОСУААРСТВ ЭКОНОМИЧЕСКИЙ СОВЕТ [Szodruzsesztvo Nezaviszmih Goszudarsztv Ekonomicseszkij Szovjet.] (2014).

Elérhetô: http://cis.minsk.by/reestr/ru/index.html\#reestr/view/text?doc $=4951$ (Letöltve: 2021.04.30.)

ФЕАЕРААЬНАЯ НАһОГОВАЯ САУЖБА. [Federalnaja Nalogovaja Szluzsba.] Elérhetô: https://www.nalog.ru/rn77/about fts/inttax/eec/. (Letöltve: 2021.03.02.)

Schnitzer-Skjosberg (2017): South-South in Action Series. The Cooperation Council of Turkic Speaking States (The Turkic Council), United Nations Office for South-South Cooperation and the Cooperation Council of Turkic Speaking States. Elérhető:

https://www.turkkon.org/assets/pdf/yayinlar/eylem-halinde-guneyguney-turk-konseyi-ve-unosscnin-ortak-raporu-7-en.pdf (Letöltve: 2021. 03.23.)

Shavialiova, MARYNA V. (2013): The Shanghai Cooperation Organisation and Central Asia's Security Challenges. In Rozanov, Anatoliy A. szerk.: The Shanghai Cooperation Organisation and Central Asia's Security 
Challenges, The Geneva Centre for the Democratic Control of Armed Forces - DCAF, Almaty-Minsk-Geneva. Elérhető:

https://www.dcaf.ch/sites/default/files/publications/documents/DCA F RP16 SCO.pdf (Letöltve: 2021.03.22.)

ThE SHANGHAi COOPERATION ORganisation. Elérhető: http://eng.sectsco.org/documents/ (Letöltve: 2021.03.21.)

TURKIC COUNCIL. Elérhető: https://www.turkkon.org/en/turk-konseyihakkinda (Letöltve: 2021.03.23.)

ТРЕнИН, АМИтРИй (2014): Украинский кризис и возобновление великодержавного соперничества. [Trenyin, Dmitrij: Ukrajinszkij krizisz i vozobnovlenyie velikogyerzsavnovo szopernyicsesztva.] Elérhető: https://carnegie.ru/2014/10/15/ru-pub-56935 (2021.05.01.)

VASA LÁSZLÓ (2021): A Türk Tanács közép-ázsiai és kaukázusi orsqágai a magyar külgazdaság perspektivájából, KKI elemzés, E-2021/08. Elérhető: https://kki.hu/wp-content/uploads/2021/03/08.-KKIElemzesek.E2021.08 TurkTanacs VasaL 20210329.pdf (Letöltve: 2021.03.30.)

VINOKUROV,EVGENY (2018): Introduction to the Eurasian Economic Union. St Petersburg Russia.

World ECONOMIC SituAtion AND PRospects (2015) Elérhető: https://www.un.org/en/development/desa/policy/wesp/wesp archive L2015wesp myu en.pdf (Letöltve:2021.05.01.)

ZyBeK-Plater, Heny - Monaghan, ANDrew (2014): Widening the net: China's anti-terror laws and buman rights in the Xinjiang Uyghur Autonomous Region, Strategic Studies Institute, US Army War College, August. Elérhetô:

https://www.jstor.org/stable/resrep11392?seq=1\#metadata info tab c ontents (Letöltve: 2021.03.22.)

ЭАЕКТРОННЫЙ ФОНА. [Elektronnij Fond.] Elérhető:

http://docs.cntd.ru/document/420229250 (Letöltve: 2021.03.03.)

ЭАЕКТРОННЫЙ ФОНА. [Elektronnij Fond.] Elérhető:

http://docs.cntd.ru/document/420246571 (Letöltve: 2021.03.03.) 